\title{
Baskıcı ve Dışlayıcı Han Milliyetçiliğinin Doğu Türkistan'da (Sincan Uygur Özerk Bölgesi) Yansımaları
}

\author{
Gülșen ȘEKER-AYDIN ${ }^{1}$ ve Müge YÜCE ${ }^{2}$
}

$\ddot{\mathrm{O} z}$

Çin Anayasası tarafından ülke içerisinde 56 farklı etnik kökene sahip halkın yaşadığı resmî olarak kabul edilmiştir. Bu halklar arasında en yüksek nüfusa sahip etnik azınlıklardan birisi Uygur Türkleri iken beş ayrı özerk bölge içerisinde en geniş alana sahip olanı Sincan Uygur Özerk Bölgesi'dir. Sincan'ın zengin doğal kaynaklara sahip olmasının yanında sekiz farklı devlet ile sınırının bulunması bölgeyi Çin için stratejik bir konuma yerleştirmektedir. Bu nedenlerle Sincan, Çin'in ulusal entegrasyon politikalarında çok önemli bir yere sahiptir. Bölge üzerinde siyasi hâkimiyetin sağlanması yalnızca güvenlik meselesi değildir; aynı zamanda, Çin Komünist Partisi'nin ekonomik ve siyasi meşruiyetini sağlamlaştıracağı bir örnek-olay teşkil etmektedir. Bu çalışmada Çin Halk Cumhuriyeti’nin “ulus-devlet” inşasını sağlamak üzere Sincan Uygur Özerk Bölgesi’nde uyguladığı nüfus, eğitim ve dil politikaları modernite ve milliyetçilik perspektifinden ele alınmıştır. Çalışmanın sonucunda Çin'in Sincan Uygur Özerk Bölgesi’nde etnik milliyetçilik anlayışına dayanan politikalar uyguladığı ve bu kapsamda özellikle nüfus, eğitim ve dil politikalarının özgürleştirici ve kapsayıcı değil baskıcı ve dışlayıcı bir güç olarak kullanıldığı ortaya konmuştur.

Anahtar Kelimeler: Modern Ulus Devlet, Azınlıklar, Çin, Sincan, Nüfus ve Eğitim Politikaları

The Repercussions of Repressive and Exclusionary Han Nationalism on East Turkistan (the Xinjiang Uyghur Autonomous Region)

\begin{abstract}
Among the 56 ethnic groups recognized by the Chinese Constitution, Uyghur Turks are one of the biggest, and the Xinjiang Uyghur Autonomous Region is the largest of five autonomous regions of the People's Republic of China. As it possesses rich natural resources and borders eight states, Xinjiang is strategically significant for Beijing. Therefore, Xinjiang looms large in the national integration policy of China. For Beijing, establishing political control over Xinjiang is not only crucial for security reasons, but it also can provide the Communist Party with an instrument to consolidate its economic and political legitimacy. This study explores the population, education, and language policies pursued by Beijing in the Xinjiang Uyghur Autonomous Region from the perspective of modernity and nationalism. As a conclusion, the study argues that rather than opting for emancipatory and inclusionary policies, in Xinjiang, China pursues ethnic nationalist policies that are repressive and exclusionary.
\end{abstract}

Key Words: Modern Nation States, Minorities, China, the Xinjiang Uyghur Autonomous Region, Demographic, Education and Language Policies

\section{Atıf İçin / Please Cite As:}

Şeker-Aydın, G. ve Yüce, M. (2020). Baskıcı ve dışlayıcı han milliyetçiliğinin Doğu Türkistan'da (Sincan Uygur Özerk Bölgesi) Yansımaları. Manas Sosyal Araștırmalar Dergisi, 9(4), 2668-2682.

Geliş Tarihi / Received Date: 17.04.2020

Kabul Tarihi / Accepted Date: 25.06.2020

\footnotetext{
${ }^{1}$ Dr. Öğretim Üyesi, Atatürk Üniversitesi İktisadi ve İdari Bilimler Fakültesi, gulsenaydin@atauni.edu.tr, ORCID: 0000-0003-1288-4053

2 Dr. Arş. Gör.- Atatürk Üniversitesi İktisadi ve İdari Bilimler Fakültesi, muge.yuce@atauni.edu.tr, ORCID: 0000-0002-7593-6060
} 


\section{Giriş}

Doğu Türkistan* ya da resmî adıyla Sincan Uygur Özerk Bölgesi’nde Çin Halk Cumhuriyeti’nin baskıcı milliyetçi politikaları ve bu politikalara karşı giderek yükselen tepkiler, milliyetçilik kuramları ile milliyetçiliğin Doğu ve Batı toplumlarında değişen yansımaları hakkındaki tartışmaları yeniden başlatacak bir zemin hazırlamışır. Nitekim 19. Yüzyıl Çin için mutlak bir geriye gidiş dönemi olsa da Avrupa'da olduğu gibi Çin'de de milliyetçiliğin ilk kez ortaya çıttığı dönem bu yüzyıl olmuștur. Bununla birlikte Kıta Avrupası'nda milliyetçilik vatandaşlık temelinde yükselen sivil ve kapsayıcı bir nitelik kazanırken Çin'de milliyetçilik, belirli bir etnik gruba ve kültürel aidiyet üzerinde şekillenerek dışlayıcı bir nitelik kazanmıştır.

Halkının \%91’i Han etnik kökenine sahip olduğundan homojen bir ulus-devlet olarak kabul edilen Çin, dünyada en kalabalık etnik azınlık nüfusa ev sahipliği yapan ülkelerin başında gelmektedir. Çin'de yapılan 2011 nüfus sayımı verilerine göre toplam nüfusun yaklaşık \%9'unu oluşturan etnik azınlıkların nüfusu 114 milyonu aşmakta ve bu rakam ile Çin, dünyanın en fazla etnik azınlığa sahip devleti olarak tanımlanmaktadır (Maurer-Fazio vd., 2015, s. 1).

Sincan Uygur Özerk Bölgesi, Çin'in beş özerk bölgesi arasında en geniş alana ve yüksek nüfusa sahip olanlarından biridir (Wu vd., 2018, s. 189). Çok-etnili ve çok-dilli sosyo-kültürel yapısına ek olarak sekiz farklı devlet ile sınırının bulunması, Sincan'ı Çin için stratejik bir konuma yerleştirmektedir.

Bölgenin stratejik önemi, tarih boyunca çeşitli nedenlerle süreklilik göstermiştir. 15. yüzyıla kadar İpek Yolu üzerindeki stratejik konumu, 16-19. yüzyllar arasında sahip olduğu verimli topraklar ve 20. yüzyılda da Sovyetler Birliği ile Çin arasındaki güvenlik koridorunun en önemli bileşenini oluşturması bölgeyi stratejik olarak önemli kılmıştır. Bununla birlikte sınırlar arası ulaşım ve iletişim zorluklarının ortadan kalkması, konumu sebebiyle Sincan Uygur Özerk Bölgesi’ni siyasal açıdan daha geçirgen ve dolayısıyla güvenlik tehditlerine açık bir hale getirmiştir. Özellikle Afganistan ve Pakistan gibi radikal hareketlere ev sahipliği yapan ülkelerle sınır komşusu olması, Pekin için bölgenin stratejik önemini "güvenlik" ile eş anlamlı hale getirmiştir. Diğer yandan, bölgenin sahip olduğu zengin yeraltı kaynaklanı ve Orta Asya'nın enerji zengini ülkelerine olan yakınlı̆̆ bölgenin stratejik değerinin enerji arz güvenliği kapsamında yeniden değerlendirilmesine yol açmıştır.

Tüm bu faktörler göz önünde bulundurulduğunda, Çin Halk Cumhuriyeti için bölge üzerinde siyasi hâkimiyetin sağlanması yalnızca güvenlik meselesi değil aynı zamanda Çin Komünist Partisi'nin ekonomik ve siyasi meşruiyetini sağlamlaştıracağı bir örnek-olay teşkil etmesi açısından önem taşımaktadır. Bu açıdan, Sincan Uygur Özerk Bölgesi üzerinde yapılacak bir inceleme, Çinli yöneticilerin milliyetçilik anlayışlarının ve Çin Komünist Partisi tarafindan bölgede uygulanan sosyal ve ideolojik aygıtların analizine ihtiyaç duymaktadır. Sincan Uygur Özerk Bölgesi’nde nüfusun çoğunluğunu oluşturan Uygurların Çin kültürü içerisinde asimile edilmesi için uygulanan en önemli aygtlar ise Çin yönetimi tarafından bölgede dil, eğitim ve kültür alanlarında uygulanan ve Uygurların sahip olduğu kültürün değiştirilmesine yönelik politikalardır (Karluk, 2017, s. 171).

Bununla birlikte Sincan Uygur Özerk Bölgesi'nin sınırları içerisinde kalan toprakların siyasi, ekonomik veya kültürel analizi daha baştan birtakım zorlukları beraberinde getirmektedir. Nitekim bölge iki bin yıldır çok çeşitli kültür ve medeniyetler arasında temas ve geçiş noktası olmuştur. Bu sebeple siyasi sınırların belirsizliği, yer ve şehir isimlerinin farklı dillerde farklı şekillerde kullanılmış olması Sincan Uygur Özerk Bölgesi'ne ilişkin tanım ve yorumlamalarda kesin ve kat'i söylemlerden uzak durulmasını gerekli kilmaktadır (Millward vd., 2004, s. 29).

Belirtilen sınırllıklar dâhilinde bu çalışmada Çin’in ulus-devlet inşasını sağlamak üzere Doğu Türkistan'da uyguladığı nüfus, eğitim ve dil politikalanı modernite ve milliyetçilik perspektifinden ele alınmıştır. Bu kapsamda çalışmanın ilk bölümünde ulus-devletlerin oluşum sürecinde etkili olan milliyetçilik akımı ve milliyetçiliğin modernite ile ilişkisi ele alınmış, Çin milliyetçiliğinin oluşum süreci ve

\footnotetext{
* Türkistan, "Türklerin ana yurdu" anlamına gelmekte ve 7. Yüzyıldan itibaren kullanılmaktadır. Bugünkü Orta Asya cumhuriyetlerini ve Sincan Uygur Özerk Bölgesi’ni kapsayan Türkistan, bölgede etkili büyük güçler olan Çarlık Rusyası ve Çin İmparatorluk yönetimleri tarafindan işgal edilerek kontrol altına alınmıştır. Batı Türkistan coğrafyasını oluşturan ve bugünkü Orta Asya cumhuriyetlerini içine alan bölge Çarlık Rusyası tarafindan kontrol altına alınırken, Doğu Türkistan bölgesi 1876 yllına Qing Hanedanlığı'nın yönetimi altındaki Çin İmparatorluğu tarafindan işgal edilmiştir (Alptekin, 1992: 185). Bugün Çin Halk Cumhuriyeti sınırları içerisinde yer alan bölge, Çin İmparatorluğu tarafindan kontrol altına alındıktan sonra "yeni topraklar" anlamına gelen 新疆 Xīn jiāng karakterleri ile adlandırılmıstır.
} 
taşıdığı nitelikler incelenmiştir. İkinci bölümde Sincan Uygur Özerk Bölgesi’nin coğrafi konumu ve tarihi kısaca ele alındıktan sonra bölgenin demografik yapısı incelenmiştir. Bu inceleme sonucunda üçüncü bölümde Çin'in Sincan Uygur Özerk Bölgesi üzerinde uygulamış olduğu nüfus, eğitim ve dil politikaları, bu politikaların tarihsel süreçleri ve günümüzde yol açtığı sonuçlar değerlendirilmiştir.

Çalışmanın sonucunda Çin'in Sincan Uygur Özerk Bölgesi’nde Kohn tarafindan yapılan sınıflandırmaya uygun olarak etnik milliyetçilik anlayışına dayanan politikalar uyguladığı ve bu kapsamda nüfus, eğitim ve dil politikalarının özgürleştirici ve kapsayıcı değil baskıcı ve dışlayıcı bir güç olarak kullanıldığı ortaya konmuştur.

\section{Modernite ve Milliyetçilik}

Milliyetçilik, siyasi birim ile ulusal birimin örtüşmesini öngören bir siyasi prensip olarak tanımlanmaktadır (Gellner, 1983, s. 1). Birçok yazar, milliyetçiliği hem bir modern dönem fenomeni, hem de modernitenin ayrilmaz bir parçası olarak görmektedir. Milliyetçiliğin modern döneme ait bir olgu olduğu fikrinden başlamak gerekirse, O' Mahony vd. (2002, s. 7) milliyetçiliğin ortaya çıması için gereken bilgi birikiminin ancak modernite ile oluştuğunu çünkü milliyetçiliğin temelini, tarih ve coğrafya bilgisinin oluşturduğunu savunmaktadır. Kedourie (1993, s.1) ise milliyetçiliğin bir doktrin olarak 19. yüzyıl Avrupası'nda ortaya çıktı̆̆ını söylemektedir. Harris'in (2009, s. 1) vurgusu da 19. yüzyıl üzerinedir ancak Kedourie'den farklı olarak Harris, bu yüzylın ortalarında dünya üzerinde milliyetçiliğin etkisinin hissedilmediği hiç bir yer kalmadığına dikkat çekmektedir.

Milliyetçiliğin modernitenin önemli bir parçası olduğu konusunda da literatürde baskın konumda olan modernist bakış açısı, milliyetçiliği modern devletin doğuşu ile ilişkilendirmektedir (Greenfeld, 2006, s. 160). Bu bakış açısına göre modern dönemde siyasi otoritenin sınırlarının devlet olarak kurumsallaşacağı ve bu yeni otoriteye halkın boyun eğmesini ve sadakatini sağlamak için de milliyetçiliğin paha biçilmez bir çözüm olarak ortaya çıkacağı varsayılmaktadır. Milliyetçiliğin yerel yöneticilerin otoritesini yok ederek otoriteyi merkezileştirmedeki rolünün büyük olacağ1 da en önemli kabullerden birisini oluşturmaktadır (Marx, 2003, s. 5-6). Milliyetçiliğin bunu yaparken temel gücünü meşrulaştırıc1 etkisinden alacağ1 varsayılmaktadır. Bu etkiyi anlamak için milliyetçiliğin ortaya çıkışında ve dünyaya yayılmasında bir dönüm noktası olan Fransız Devrimi’ne ve halk egemenliğinin ortaya çıkışına odaklanmak gerekmektedir.

'Özgürlük, Eşitlik ve Kardeșlik', Aydınlanma düşüncesinden ve özellikle Fransız düșünürü Rousseau'nun fikirlerinden beslenen Fransız Devrimi'nin temel sloganı olmuştur (Censer, 2001, s. 14-21). Rousseau için siyasal toplumun temel prensipleri katılım ve vatandaşlık olmuştur. İnsan ve Vatandaş Hakları Bildirgesi, egemenliğin tek kaynağı olarak ulusu kabul etmiş; hiçbir grubun ya da bireyin ulustan kaynağını almaksızın egemenliği kullanamayacağını ilan etmiştir (Janis, 1992, s. 480). Devrim fikirlerinin yayllması ile birlikte ulusal egemenlik, hem devletin içinde hem de uluslararası arenada siyasi otoritenin temel meşruiyet kaynağı olarak mutlak monarşinin yerini almaya başlamıştır (Keitner, 2007, s. 69).

Milliyetçilik, bölge, yerel gelenekler ve klanlar gibi yerel çaptaki kısıtlı çerçevesi olan kimliklerin kurduğu duvarlanı yıkmış ve bu kimlikler yerine daha kapsamlı olan ulus devlete dayalı kimliği ön plana çıkarmıştır. Dahası, milliyetçilik feodal pratikleri ortadan kaldırarak tiranlığın yerine halkın egemenliğini savunmuştur (Smith, 1998:1). Feodal toplum yapısı içinde üst bir konuma yükselme mümkün değildi; toplumdaki katı hiyerarşide kısıtlı bir kesim toplumda önemli ayrıcalıklara sahipken geri kalanı her haktan mahrum bırakılmış ve aşağılanmıştır. Halk egemenliğinin tanınması ise bu durumun değişmesine yol açmıştır (Greenfeld, 1996, s. 13). Bu yüzden ilk başlarda milliyetçilik kucaklayıcı ve özgürleştirici bir güç olarak ortaya çıkmıştır (Smith, 1998, s.1). Bu bağlamda Bendix, modernizasyonu tipik geleneksel düzenin çöküşü olarak tanımlar: dinî otorite kutsallığını kaybeder, monarşi düşüşe geçer, hiyerarşik sosyal düzen alt üst olur. Bunların yerine seküler otorite, halk egemenliği ve eşitlikçi değerler sistemi modern toplumun temel sacayakları olarak ortaya çıar $(1978$, s.11). Moderniteden önce toplumu katı şekilde tabakalara ayıran hiyerarşi, toplumun temel çatısı iken, bu çatı yıkılır ve yerini toplumun her üyesinin eşit kabul edilip eşit muamele gördüğü yeni bir düzene birakır (Schmidt, 2010, s. 521).

\section{Milliyetçiliğin Dönüşümü: Kapsayıcı Milliyetçilikten Dışlayıc1 Milliyetçiliğe}

Halk egemenliği kavramı Fransız Devrimi ile birlikte ulus devletin temelini oluşturmaya başlamıştır ancak ulusu ne oluşturacaktır? Ulusal aidiyeti tanımlamak artık bir zorunluluk haline gelmiştir. Bu noktada Rousseau'nun eşit vatandaşlık hakları çerçevesinde ulusu tanımladığı siyasi çerçeveye Alman romantizmi, 
ulusun tarih ve gelenek çerçevesinde tanımlandığı kültürel çerçeveyi eklemiştir (Harris, 1999, s. 23-24). Alman romantizminin önemli isimlerinden Herder'e göre ulusu yaratan devlet değil doğaydı (Berlin, 1980, s. 158). O, toplumsal dayanışma ve kan bağının önemine inanıyordu; O'na göre doğanın dillerine, geleneklerine, karakterlerine göre ayırdığı halkları suni olarak birleştirmeye çalışmak barbarlıktır (Berlin, 1980, s. 159).

Aslında Herder'in yaptığ 1 her ulusun kendini ifade etmesine izin verilmesini savunmak ve ulusları tanımlarken en önemlisi dil olan değişik kültürel özellikleri ön plana çıarmaktır. Ancak daha sonraki aşamalarda onun fikirleri ve Alman romantizmi çerçevesinde ulusların tanımlanması, çeşitli olumsuz sonuçlar doğurmuştur. Milliyetçiliğin doğduğu İngiltere ve Fransa gibi Batı Avrupa ülkelerinde diğer yerlere göre daha güçlü olan monarşiler, ekonomik gelişim, ticari bütünleşme, bürokratikleşme, milli eğitimin yaygınlaşması, iletişimin ilerlemesi ve seçme-seçilme haklarının yaygınlaşması gibi gelişmelerin de yardımıyla siyasi-kültürel bölünmeleri kapsamlı ulus devlet kimliği içinde eritmeyi başarmışlardır (Tilly, 1975). Ancak, Orta ve Doğu Avrupa gibi hem ekonomik hem de siyasi anlamda modernleşmede Batı Avrupa'nın gerisinde olan yerlerde süreç farklı işlemiştir. Bu coğrafyada yeni elitlerin taleplerini Batı Avrupa'daki gibi siyasi haklarla karşılayıp nüfusu ortak haklar çerçevesinde bütünleştirmek yerine ortak kimlik oluşumunda dilsel, dini ve folklorik ögeler vurgulanmıştır (Roshwald, 2001, s. 5).

Bu durumda milliyetçilik özgürleştirici ve kucaklayıcı olmaktan uzaklaşmış; tam tersi baskıcı ve dışlayıcı bir form almıştır. Bir milletin ya da etnik grubun üyesi olmak modernitenin sağladığı siyasi katılım ve kanunlar önünde eşitlik gibi haklara ulaşabilmenin ön koşulu haline gelmiştir (Wimmer, 2002, s. 1). Sonuçta 20. yüzyllın başlarında dünyanın dört bir tarafinda yerel elitleri imparatorluklara ve koloni yönetimlerine karşı harekete geçiren ve demokrasi ile yakından ilişkilendirilen milliyetçilik, dilsel ve kültürel farklılıkları vurgulayan elitlerin başarıları paralelinde Versay Antlaşması ile Avrupa'nın siyasi haritasını derinden değiştirmiştir. Ancak giderek dışlama, şiddet ve baskı ile eşleşmeye başlamıştır (Smith, 1998, s. 2). Kültürel farklıllğın ulusal güvenliği tehdit ettiği düşüncesiyle girişilen nüfusu homojenleştirme politikaları, iki dünya savaşı arası dönemde Nazilerin gerçekleştirdiği soykırımlarla son noktaya dayanmıştır (Conversi, 2012, s. 15). Böyle olunca, milliyetçilik artık demokrasi ile değil de farklı olanı yok etme ile özdeşleştirilmeye başlanmıştır. Örneğin Nairn'e (1975, s. 17) göre Faşizm milliyetçilik hakkında bize diğer her şeyden çok daha fazla şey anlatmıştır.

Bask1 ve dışlama özellikle etnik milliyetçiliğin uygulandığ1 ülkelerde azınlıkların kâbusu haline gelmiştir. Bu noktada tartışma bizi birçok yazarın kabul ettiği sivil (vatandaşılı temeli üzerinde yükselen) milliyetçilik ve etnik milliyetçilik ayrımına getirmektedir. Bu ayırımı ortaya atan Kohn, milliyetçiliğin batıda ve doğuda farklı özelliklerinin olduğunu savunmakta ve batıdaki milliyetçiliği sivil ya da vatandaşlık temelinde yükselen milliyetçilik, doğudaki milliyetçiliği ise etnik milliyetçilik olarak sınıflandırmaktadır (Calhoun, 2008, s. IX). Milliyetçilik batıda sivil kurumlara ve burjuvaziye dayanan bir sosyal tabana sahiptir. Bu kurumların ve sınıfların olmadığı doğuda ise milliyetçiliğin temeli daha çok entelektüeller tarafından oluşturulan bir ulusal fikre dayanmaktadır. Batıda milliyetçilik ya ulus devletlerin doğuşundan önce gelişmiştir ya da ulus devlet kuruluş süreci ile birlikte şekillenmiştir. Doğuda ise milliyetçilik ulus devletlerin ortaya çıkışından sonra gelişmiştir ve mevcut devletlerle çatşsma içinde olmuştur (Kohn, 1944, s. 329-30). Batıda milliyetçilik bireysel özgürlük, akılcılık ve parlamenter demokrasi ile ilgilidir. Doğuda ise halk kültürü, dil ve etnisite milliyetçiliğin temel odak noktaları olmuştur (Kohn, 1994, s.162-165).

Plamenatz da Batı Avrupa milliyetçiliği ile Afrika, Asya ve Latin Amerika'da görülen "doğuya ait milliyetçilik" arasında ayırım yapmıştır. Yazar, batıda milliyetçiliğin çoğu zaman liberal olduğunu (Plamenatz, 1973, s. 29), doğuda ise çoğunlukla baskıcı davrandığını vurgulamıştır (Plamenatz, 1973, s. 25). Burada dikkat çeken batının kendi milliyetçiliğini yüceltmesi, doğunun milliyetçiliğini ise ötekileştirmesidir (Gökalp, 2007, s. 285).

Yine sivil ve etnik milliyetçilik ayırımını kullanan Goldman vd., sivil milliyetçiliğin hâkim olduğu toplumlarda farklılıkların göze çarpmadığını, etnik milliyetçiliğin hâkim olduğu toplumlarda ise farklılıkların (acı bir şekilde) göze battığını savunmuştur. Sivil milliyetçiliğin egemen olduğu toplumlarda farklılıkların görünür olmamasının nedeni gerçekte farklılıkların olmaması değil, farklılıkların değişik algılanmasıdır. Bu toplumlar etnik farklillğı toplum fertlerinin kimliklerinin temel tanımlayıcısı olarak görmezler (Goldman vd., 2016, s. 24). Ancak etnik kökenin vatandaşların kimliğini tanımlayan temel öğe olduğu etnik milliyetçiliğin hâkim olduğu toplumlarda etnik farkl11ıklar, doldurulması olanaksız uçurumlar yaratır ve toplumsal barışı tehdit eder (Goldman vd., 2016, s. 26). Bu durumda, modern öncesi dönemdeki azınlığın 
çoğunluğu kontrol ettiği düzen tersine çevrilir ve modern dönemde çoğunluğu oluşturan etnik grubun bask1 uygulayarak azınlıklar1 kontrol etmesi temel kural haline gelir (Kaufman vd., 2008, s. 746).

Doğuda görülen milliyetçiliğin her zaman baskıcı ve dışlayıcı, Batıda görülen milliyetçiliğin ise her zaman kapsayıcı olduğu görüşünü kabul etmek zor olsa da milliyetçiliğin bir tarafta baskıcı ve dışlayıcı, diğer tarafta da kapsayıcı ve özgürleştirici biçimleri arasındaki ayırım oldukça anlamlıdır. Modern dönemin başlarında özgürleştirici ve kapsayıcı bir güç olan milliyetçilik, özellikle etnik milliyetçiliğin hâkim olduğu toplumlarda zamanla baskıcı ve dışlayıcı bir güce dönüşmüştür. Nitekim, bir sonraki bölümde de tartışlacağı gibi, Çin İmparatorluğunun son dönemlerinde ortaya çıkan milliyetçilik de zamanla bu tür bir dönüşüm geçirerek etnik azınlıklara karşı izlenen baskıcı politikaların zeminini oluşturacaktır.

\section{Çin Kültüründe "Medeni-Barbar İkilemi” ve Çin Milliyetçiliği}

Modern Çin milliyetçiliğinin kökleri, 1636 ile 1911 arasında Çin’i yöneten Qing Hanedanlığı süresinde gelişen kimlik dinamiklerine dayanmaktadır. Bu milliyetçilik, Çin sınırları içinde yaşayan herkesi Çin milleti olarak tanımlamaktadır. Buna göre Çinli olmak için Han kökeninden gelmeye gerek yoktur. Fakat Çin kimliği üniter bir kimlik olduğu için Çin'in siyasi üstünlüğünü kabul eden halkların zaman içerisinde Çinlileşmeye başlamaları beklenmektedir. Modern dönem Çin milliyetçiliği üzerinde önemli etkisi olan bu anlayış, Çince'de hua-yi olarak tanımlanmaktadır. Geleneksel Konfüçyen düşüncenin bir ürünü olan ve dünyayı medeni-barbar ikiliği 華夷之辨 huá yí zhī biàn içerisinde gören bu anlayışa göre hua; “medeni”" olarak kabul edilen Çin kültürünü ve Çinli halkı, yi ise "barbar" olarak kabul edilen Çin sinırları dışında kalan ve etnik azınlıkların yaşadığı bölgeleri de içine alan dış çevreyi temsil etmektedir (Pekcan, 2017, s. 1128).

Bu sebeple Çin milliyetçiliğinin tüm etnik azınlıklara karşı asimilasyonist bir tutumu teşvik eden üniter bir ulusal kimlik ile karakterize edildiği kabul edilmektedir (Odgaard vd., 2014, s. 546). Bu yönüyle Çin milliyetçiliği Kohn tarafından yapılan sınıflandırmaya uygun olarak halk kültürü, dil ve etnisitenin milliyetçiliğin temel odak noktalarını oluşturduğu etnik milliyetçiliğin özelliklerini taşımaktadır (Kohn, 1994, s. 162-165).

Çin'de modern anlamda "millet” anlayışının oluşması 19. Yüzyılda yaşanan Afyon Savaşları sonrasına rastlamaktadır. Bu dönemde yabancı işgalcilere karşı verilen ulusal mücadele, Çin'de "millet" anlayışının yaygınlaşmasına yol açmışır. İlk olarak Avrupa'da ortaya çıkan "ulus", "ulus-devlet" ve "milliyetçilik" kavramları, Çin'de ancak Afyon Savaşları sonrasında kavramsallaştırılmıştır (Ma, 2017, s. 1). Bu kavramsallaştırmaya göre 1949 'da Çin Halk Cumhuriyeti kurulduktan sonra iki seviyeli bir ulusal yap1 oluşturulmuştur. Bu yapi içerisinde Han etnik grubu 汉族 Hàn zú üst kimliği oluştururken, diğer tüm etnisiteler 民族 mín zú Han Çinlilerinin altında konumlandırılmış ve tüm yapının tamamı Çin ulusu 中华 民族 Zhōng huá mín zú olarak tanımlanmıştır (Ma, 2014, s. 237).

Han etnik kimliği ile azınlıklar arasındaki ilişkilere yönelik tartışmalar, Çin'de milliyetçiliğin ortaya çıktı̆̆ 19. Yüzyılda yaygınlaşmaya başlamakla birlikte Çin yönetimi tarafindan etnik azınlıklar ilk kez 1959 yılında resmî olarak tanımlanmıştır (Fan, 2016, s. 2096). Sovyet Sosyalist Cumhuriyetler Birliği tarafından kabul edilmiş olan “milliyetler” ile benzer şekilde Çin'de 55 etnik milliyet “azınlık etnik gruplar" 少数民族 shăo shù mínzú, Han milliyeti ise "çoğunluk" olarak tanımlanmıştır (Joniak-Lüthi, 2016, s. 2188).

Çin milliyetçiliğinin bileşenlerinden bir tanesi emperyal miras olmakla birlikte, 1949 sonrası politikaları belirleyen bir diğer önemli etken de Marksist-Leninist mirastır (Christiansen ve Rai, 1996, s. 291). Nitekim "Sincan Uygur Özerk Bölgesi” düşüncesi, Sovyet hâkimiyeti altındaki Orta Asya’nın etnik ve milliyetçi sorunlarını çözmek için Stalin’in ilk kez bölgeye uygulamıs olduğu formüle dayanmaktadır (Sharpe, 2012, s. 9). Ancak, teoride "milli azınlıklara ayrılma hakkının verildiği federal cumhuriyetlere dayanan" bir sistem benimseyen Sovyetler Birliği’nin aksine Çin Halk Cumhuriyeti etnik farklılikları yönetmek için "sınırlı topraksal özerkliğin verildiği” bir sistem kurmuştur (Clarke, 2011, s. 48).

1934'e kadar ulusal azınlıklara self-determinasyon hakkının verilmesini içeren Sovyetler Birliği modelini izleyen Çin Komünist Partisi, Mao'nun iktidarı ile birlikte duruşunu değiştirmiştir. Bu kapsamda özellikle 1931'de Japonya'nın Mançurya'yı işgali ile pekişen milliyetçi duygular ve Han şövanizmi, Çin Komünist Partisi yönetimine Mao'nun geçmesinden sonra anti-emperyalist retorik ile birleşerek ulusal azınlıklara yalnızca "bölgesel özerklik" verilebileceğine yönelik söylemlerin benimsenmesine yol açmıstır (Shih, 2002, s. 235). Nitekim Çinli yöneticilerin 19. Yüzyıldan itibaren coğrafî sınırları açık ve net bir biçimde belirlenmiş özel bir egemenlik olarak tanımlanabilecek Westphalian sistemi yani modern ulus 
devlet sistemini benimsemeleri sebebiyle 1949 yllinda kurulan Çin Halk Cumhuriyeti, siyasi yetki ve toprak arasındaki ilişkiyi yeniden düzenleme ihtiyacı duymuştur. Bu tarihten sonra Çin, Westphalian egemenliğin bir unsuru olarak önce kontrol mekanizmasını genişletmek ve daha sonra sağlamlaştırlan siyasi nüfuzun meşrulaştırılmasına yönelik politikalara ağırlık vermiştir (Clarke, 2011, s. 4).

\section{Sincan Uygur Özerk Bölgesi’nin Siyasi Tarihi ve Etnisiteler Arası İlişkiler}

Doğu Türkistan bölgesini oluşturan ve bugün Sincan Uygur Özerk Bölgesi’ni sınırları içerisine alan bölge, Orta Asya Türk tarihinin bir parçası olarak Hun ve Göktürk İmparatorluklarının sınırları içerisinde yer almıştır (Başkaya, 2019, s.216). Sincan coğrafyasının politik görünümünü etkileyen en önemli rekabet, M.Ö. 162'de Doğu Türkistan bölgesine gelen Türk kavmi göçebe Hunlar ile Çin ana karasında yerleşik olan Çinliler arasında 19. yüzyıla kadar devam eden hâkimiyet mücadelesi olmuştur. Bu uzun dönem boyunca Sincan, kimi zaman Türk ve Çin Hanlıklarının hâkimiyeti altına girerken kimi zaman yerel beyliklerin yönetimi altında yarı-bağımsız bir statüde kalmıştır. Bununla birlikte Sincan'ın nüfus yapısı altıncı yüzyılda Çin'de güç kazanmaya başlamış olan Tang Hanedanlığının siyasi politikaları ile Türkleşmiş ve 9.-13. yüzyıllar arasında bölgede etkili olan Karahanlılar döneminde İslamlaşmıştır (Millward vd., 2004, s. 46). Bilinen ilk Uygur Devleti, 744'te Kutluk Kül Bilge Kağan tarafindan kurulmuştur. Bu ilk Uygur Devleti, 840 yılında Kırgızlar tarafindan yıkılmış ve bünyesinden üç ayrı Uygur kökenli devlet çıkmıştır: İdikut (Turfan) Uygur Devleti $(840$ - 1275), Kensu Uygur Devleti $(870$ - 1225) ve Karahanlı Devleti $(870$ - 1213) (Körpe, 2013, s. 18-19). Bu yüzylllar boyunca Uygur Türklerine ait olan Doğu Türkistan, 19. Yüzyıldan sonra Çin'e bağlı Sincan Uygur Özerk Bölgesi olarak tarihe kaydedilmiştir (Sayın vd., 2017, s.22).

Bölgenin Türkleşme ve İslamlaşma sürecinin yaşandığı 9-13. Yüzyıllar arasında Sincan ve çevresi çeşitli etki alanlarına bölünmüştür. Bununla birlikte bu tarihler boyunca bölgede daha önce hiçbir toplumun yaşamadığ kadar uzun süre kalan toplum, 744 yllından 840 yllına kadar kendi imparatorluklarına sahip olan fakat daha sonra Karahitayların derebeyliğini kabul etmiş olan Uygurlardır (Millward vd., 2004, s. 41). Uygurların yeterli askerî güce sahip olmamaları sebebiyle bölgede çeşitli dönemlerde güç kazanan Türk, Moğol ve Çin hanlıklarının hâkimiyetleri Sincan'a önemli bir siyasi miras bırakmıştır. Tüm bu dönemler boyunca küçük krallık ve beylikler tarafindan değişen ölçülerde özerklik ile yönetilen bölge halkının siyasi tutumu, bağımsızlık yönünde şekillenmiştir (Clarke, 2011, s. 16). Bu bağımsızlık ruhunun da etkisiyle Çin'in Mançu etnik kökenli Qing Hanedanlığı’nın Sincan coğrafyasına girdiği 1759 yllından Yakup Bey'in iktidara geldiği 1865 yllına kadar süren yüz on yıllık zaman diliminde Çin yönetimi, yerli halkın direnişleri sebebiyle bölgede tam hâkimiyet kuramamıstır (Karaca, 2017, s. 221). Çin yönetiminin bu dönemde bölgede hâkimiyet kuramamasının ve hâkimiyet kurma çabalarının başarısız olmasının önemli sebeplerinden bir tanesi de Çin'in iç ve dıştan gelen çeşitli meydan okumalarla karşı karşıya kalmasıdır. Nitekim Çin'in Afyon Savaşları (1839-1842) ve izleyen ylllarda meydana gelen Taiping (1851-1864) ve Nian (1851-1868) ayaklanmalarıyla zayıflaması Doğu Türkistan'da güç kaybetmesine neden olan faktörler arasındadır (Demirağ, 2014, s. 233).

Qing Hanedanlığ1 18. yüzyılda Sincan'1 ilk kez yönetimi altına almak istediğinde hanedanlık yöneticileri, 600.000 üzerinde nüfusa ve iki milyon $\mathrm{km}^{23}$ nin üzerinde bir alana sahip olan bölgeyi yönetsel açıdan hâkimiyet altına almanın zorluklarıyla yüz yüze kalmışlardır. Bu zorlukların farkında olan Qing Hanedanlığ1 yöneticileri, Sincan'daki hâkimiyet araçlarını yerel toprak beylerinin çıkarlarına uygun, antimüdahaleci ve esnek bir yapı içerisinde inşa etmişlerdir. Dolayısıyla 1884'de resmî eyalet statüsü verilene kadar Sincan'ın Çin'in bir mandası olduğunu söylemek zordur (Millward vd., 2004, s. 46). Bu dönemde, özellikle de Qianlong’un hükümdarlığı boyunca (1736-95), Mançular, Han Çinlileri, Moğollar, Tibetliler ve Müslümanlar hiyerarşik bir yapı içinde yaşamıyorlardı; yatay düzlemde seyreden ilişkilere sahiptiler (WaleyCohen, 2004, s. 198). Bu bağlamda, modernite ve milliyetçilik bölümünde tartışıldığ1 gibi, modern öncesi bu dönemde toplum etnisiteye göre sınıflandırılmamış; Han Çinlileri etnik hiyerarşinin tepesinde yer almamıstır. Ancak, bu durum 19. Yüzyll ile birlikte değişmeye başlamıstır.

Sincan'da Qing Hanedanlı̆̆ı'nın hâkimiyetine karşı Yakup Bey ve Hoca Niyaz Hacı önderliğinde meydana gelen milliyetçi ayaklanmalar imparatorluk yönetiminin Sincan'a yönelik politikalarının radikal şekilde dönüşmesine yol açmıştır. Bu ayaklanmaların en önemlilerinden bir tanesi Yakup Bey tarafindan 1864 yılında tüm Doğu Türkistan'ı birleştirmek için başlatılan mücadeledir. Haziran 1877'de Yakup Bey'in ani ölümüyle oğulları ve kumandanı arasında çıkan taht kavgasını firsat bilen Çin, Doğu Türkistan’ı işgal ederek Yakup Bey'in devletine 1878 yllına gelindiğinde tamamen son vermiş̧ir (Adıbelli, 2008, s.49-50). 
Ancak, Sincan'da imparatorluk kontrolünün daha sık1 şekilde kurulması ve yönetsel araçlarla bölgenin bütünleştirilmesi sorunsalı yalnızca bölgede meydana gelen ayaklanmaların bir sonucu olarak ortaya çıkmamıştır. 19. Yüzyllın son dönemlerinde Qing İmparatorluğu çözülmeye başlamış, halk nezdindeki meşruiyetini yitirmiş ve iç ayaklanmalar sonrasında dış tehdit algisı güçlenmiştir. Qing yönetimi, Rusya ve Britanya'nın Orta Asya'da etki alanlarını genişletmeye yönelik politikaları ve sınır bölgelerinde askerî faaliyetlerini arttırmaları sonucunda bölge üzerindeki iktidarını ve meşruiyetini sağlamlaştırma ihtiyacı hissetmiştir. Bu ihtiyaç üzerine Qing İmparatorları, Sincan'1 1870'li yılların ilk yarısında ikinci kez işgal ederek 1884'de bölgeye resmî eyalet statüsü vermiş ve bölgenin imparatorluk ile bütünleştirilmesine yönelik politikalar izlemeye başlamışlardır (Dillon, 1998, s. 357). Bu dönemde izlenen politikaların en önemli boyutlarından bir tanesi, Sincan ekonomisinde tarımın ticarileştirilmesi ve Rus İmparatorluğu ile Britanya arasındaki rekabetten faydalanarak Sincan'ın diş ticaretteki rolünün artırlması olmuştur (Atli, 2011, s. 116). Bunlara ek olarak, Sincan'ın Çin'in geri kalanı ile bütünleştirilmesini hedefleyen 19. Yüzyıl politikaları bölge halkını asimile etmek üzerine kurulmuş ve siyasi farkllıklara ve esnek yönetime izin veren 18. Yüzyıl politikalarından farklılaşmıştır (Millward vd., 2004, s. 63).

\section{ÇKP'nin Bütünleştirme Aracı Olarak Sincan'da Nüfus Politikası}

Komünist Parti'nin Sincan'ı Çin kültürü, ekonomisi ve etnisitesi ile tam olarak bütünleştirme (asimile etme) amacının kendi içinde geçerli ideolojik, ekonomik veya devlet güvenliğini içeren sebepleri tarih boyunca var olmuştur. Bununla birlikte yönetimin bu amaca ulaşmak için izlediği politikalardan Sincan'ı yapısal olarak en çok etkileyeni bölgeye kitlesel Han göçünü teşvik eden resmî nüfus politikaları olmuştur. ÇHC bu toprakların asıl sahibinin Uygur Türklerinin olduğunu görmezden gelerek günümüzde Han Çinlisi göçmenlerini bu bölgeye yerleştirip demografik yapıyı değiştirmeyi amaçlamıştır (Sayın vd., 2017, s.11). Özellikle 1950-1980 döneminde aktif olarak teşvik edilen Han göçü sonrasinda Sincan nüfusunun 1947'de yaklaşık \%6'sını oluşturan Han nüfusu, 2000 yılında toplam nüfusun \%40,6' sına yükselmiştir (Millward 2007, s. 307).

Sincan çatışmasının temelleri, devletin resmî ve gayri resmî politikaları tek tek incelendiğinde daha iyi anlaşılabilir; Çin resmî kültür politikası eşitlikçi ve uyumluluk üzerine kurulurken gayri resmî politikası 1980'lerden itibaren Sincan'daki Türk azınlığın asimilesine odaklanarak Çin kültürünü baskın hale getirmek olmuştur (Dağcı vd., 2013, s.18). Çin yönetiminin asimilasyon amaçlı en önemli resmî politikalarından bir tanesi, Kültür Devrimi döneminde yoğun şekilde uygulanan ve bölgeye Han etnik kökenli genç nüfusun yerleşimini teşvik eden 下放 xià fàng hareketi olmuştur. 22 Aralık 1968 yllında Mao tarafından ilan edilen Köylüleşme Hareketi kapsamında Shanghai ve diğer büyük şehirlerde yaşayan gençler, Çin'in iç kısımlarındaki gelişmemiş bölgelere göç etmeye teşvik edilmiştir (Laifong, 2005, s. 931). Oturma izinleri daimi olarak Sincan'a alınan Han etnisitesine sahip "köylüleştirilen nüfus", Shanghai veya geldikleri diğer bölgelere geri dönmek istemelerine rağmen 1980'li yıllara kadar geri dönüşlerine izin verilmemiştir (Bovingdon, 2004, s. 24).

Sincan'da xià fàng hareketinin başlıca üç amaca yöneldiği kabul edilmektedir. Bunlar kalkınma, etik ve demografi ile ilgili kaygıların giderilmesi amaçlarıdır (Clarke, 2011, s. 63).

Tablo 1. Sincan Uygur Özerk Bölgesi Demografik Yapısı 1945-2010

\begin{tabular}{lcccccc}
\hline & 1945 & 1982 & 1996 & 2008 & 2010 \\
\hline Han (\%) & 6.2 & 40.3 & 41.1 & 39.2 & 40.4 \\
Uygur (\%) & 82.7 & 45.7 & 50.6 & 46.1 & 45.8 \\
Hui (\%) & 2.8 & 4.3 & 4.9 & 4.5 & 4.5 \\
Kazak (\%) & 1.1 & 6.9 & 8.0 & 7.1 & 6.5 & 2.0 \\
Diğer (\%) & 7.2 & 2.8 & 2.8 & 3.1 & 21.3 & 21.8 \\
\hline Toplam (Milyon) & 3.6 & 13.1 & 16.8 & 21.3 \\
\hline
\end{tabular}

Tablodan görüldüğü üzere Sincan'da Han nüfusundaki dramatik artıs 1980'li yıllara kadar izlenen teşvik politikaları sonucunda gerçekleşmiştir. 1980'li yıllardan itibaren bölgede Uygurlar ile eşit oranda nüfusa sahip olan Han göçmenlerinin ekonomik refah ve sosyal statülerinin iyileştirilmesi ve Sincan'in Han etnik kökene sahip yöneticiler tarafından kontrol edilmesi başlıca iki kurum aracilığılla sağlanmıştır. Bunlardan ilki, bölgeye askerî kontrol ve güvenlik gerekçesiyle yerleştirilen Çin Halk Kurtuluş Ordusu (PLA) mensubu asker ve aileleri olmuştur. Bununla birlikte Sincan'da sosyal ve siyasi kontrolün merkezi, 
Han göçünün teşvik edilmesini sürdürülebilir k1lma görevini üstlenmiş olan Sincan Üretim ve İnşa Teșkilatı olmuștur.

Çincede kısaca Bingtuan olarak anılan bu yapı, Sincan'da hem askerî kontrol ve zirai gelişim hem de ekonomik yap1 ve altyapının geliștirilmesinden sorumlu bir kurumdur (Howell vd. 2011, s. 123; Toops, 2016). Bingtuan'ın kuruluş amaçları, Sincan'ın ekonomik gelişiminin sağlanması, sınırların korunması ve etnisiteler arası uyumun pekiştirilmesi olarak açıklanmaktadır. Fakat kendi güvenlik güçleri, sosyal güvenlik sistemi ve özerk karar alma organları ile birlikte Bingtuan, paramiliter özellikler taşıyan "devlet içinde devlet” görünümü arz eden bir kurum niteliğindedir. Benzer şekilde Bingtuan’ın Sincan Özerk Bölgesi'ndeki dağılımı ve konumlanışı, Çin Komünist Partisi'nin kontrol ve bütünleştirme araçlarını yansıtması açısından önem taşımaktadır. 1954'de kurulan Bingtuan, Sincan'da merkezî yönetimin kontrol kurmakta en çok zorlandığı Kaşgar, Ili Tacheng ve Altay bölgelerinde konumlanmıştır (Clarke, 2011, s. 46). "İ̧ güvenlik zafiyeti" taşıyan bu bölgelerde kurumsal altyapısını oluşturan Bingtuan, bölgeye göç eden Han göçmenlerine istihdam ve barınma firsatları sağlayarak bu bölgelerdeki demografik ve ekonomik yapının değişimini hızlandırmıştır. Nitekim 1954'te kurulduğunda 200.000 olan Bingtuan'ın nüfusu, üç yll sonra 1957'de 300.000, 1966'da ise 600.000'e yükselmiştir (Millward, 2007, s. 253).

Bingtuan bünyesinde istihdam edilmek üzere Sincan'a yöneltilen kitlesel Han göçünün yoğunlaştı̆̆1 1950’li yılların sonu aynı zamanda Sovyetler Birliği ile Çin'in ideolojik olarak ayrılmaya başladıkları ve sınır anlaşmazlıkları yaşadıkları dönemdir. Bu kapsamda Sovyetler Birliği ile yaşadığı ideolojik ayrılık ve askeri tehdit olasıllọ̆, Çin’in Sincan'a daha fazla Han göçünü teşvik etmesini meşrulaştıran bir araç olarak kullanılmıştır. Aşağıdaki tablodan da görülebileceği üzere Sincan’a Han göçünün en fazla olduğu tarihler 1960-1964 aras1 dönemdir (Howell vd., 2011, s. 122).

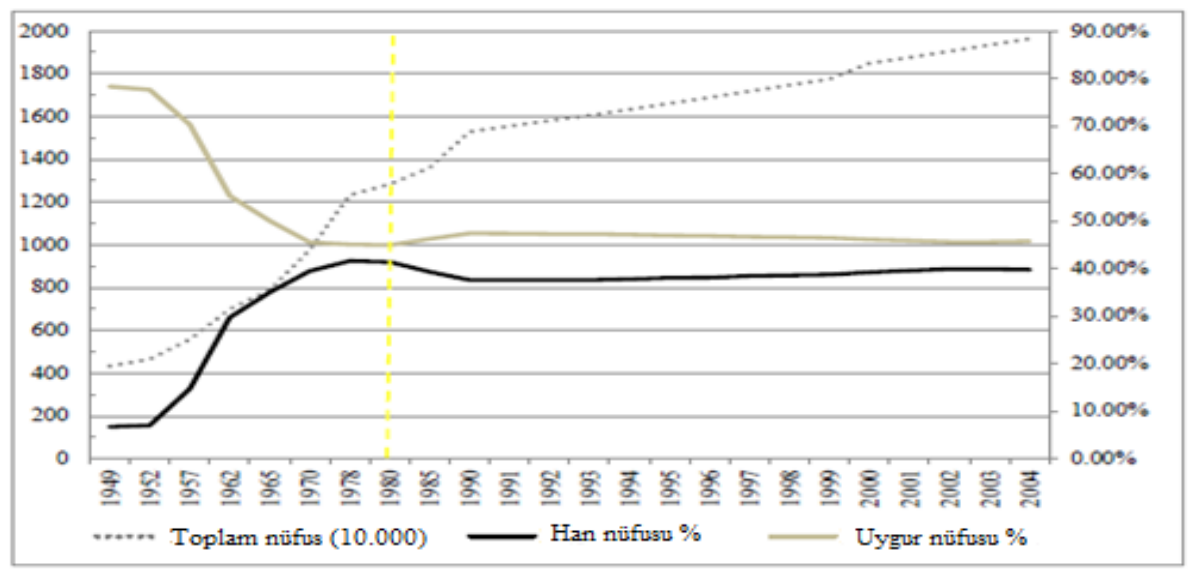

Grafik 1. Sincan Nüfusunun Etnik Bileșenlerinin Değģsimi 1949-2004 (Kaynak: Wu vd. 2013, s. 28)

Çin’in Sovyetler Birliği ile "komünist ideolojiye bağlllık" kapsamında yaşadığı ayrllıktan sonra Komünist Parti yönetiminin azınlıklara yönelik politikaları yeniden şekillenmiş ve daha katı hale gelmiştir. 1957-1962 döneminde uygulanan Büyük İleri Atılım ve 1966-1976 tarihleri arasındaki Kültür Devrimi sırasında Çin yönetimi uluslararası sistemde meydana gelen gelişmelerin de etkisiyle Sincan'da siyasi kontrolün pekiştirilmesi ve bölgeye Han göçlerinin teşvik edilmesi sürecine hız vermiştir. Nitekim gerek 1968'de Sovyetler Birliği'nin Çekoslovakya'yı işgali gerekse de aynı tarihte Sincan'da Doğu Türkistan Halk Partisi (ETPP)'nin kurulması ile Çin yönetiminin ulusal toprak bütünlüğüne yönelik tehdit alg1s1 güçlenmiştir. Bu gelişmelerin etkisiyle Çin Komünist Partisi, Sincan'ın asimilasyon yoluyla bütünleștirilmesi politikasını kitlesel Han göçlerini yoğunlaştırarak sağlamıştır (Clarke, 2011, s. 70). Sincan'da yerleşmesi teşvik edilen Han nüfusun çoğunluğu Çin'in Sichuan, Henan ve Gansu bölgelerinden gelmekte ve Sincan'in en gelişmiş bölgesi olan merkezine yerleşmektedirler. Bu göçler sonucunda Sincan'da nüfus kuzeyde Kazak etnisitesinin, güneyde Uygurların ve merkezde Han Çinlilerin yoğunluk gösterdiği bir demografik yap1 sergilemektedir (Toops, 2004, s. 24). 


\section{ÇKP'nin Bütünleştirme Aracı olarak Sincan'da Dil ve Eğitim Politikası}

Modernite sonrası milliyetçiliğin ortaya çıkmasında ve ulus-devletlerin inşa edilmesi sürecinde merkezi yönetimler tarafindan kullanılan en etkili araçlardan birisi eğitim politikaları iken, bir diğeri de ortak dilsel ögelerin vurgulanmasıdır (Tilly, 1975 ve Roshwald, 2001, s. 5). Bu anlamda eğitim sistemi ve dil politikasının vatandaşlar üzerinde nasıl uygulanacağının belirlenmesi, merkezi devlet otoritesi tarafından benimsenen milliyetçilik modeli tarafindan belirlenmektedir (Zhou, 2012, s. 27). Çin Halk Cumhuriyeti'nin azınlıklar üzerinde uyguladığı eğitim ve dil politikalarının analizi, Çin Komünist Partisi tarafindan benimsenen milliyetçilik anlayışını ve ulus-devlet inşa sürecini açığa çıkarması açısından önem taşımaktadır.

Çin Halk Cumhuriyeti'nde Deng Xiaoping döneminde kabul edilen 1982 Anayasası'na göre mevcut Çin milli eğitim sistemi, azınlık çocuklarının ulusal dil olan Mandarin'i öğrenmelerini şart koşmakla birlikte okullarda kendi anadillerini öğrenebilmeleri prensibi üzerine kurulmuştur (Cappelletti, 2015, s. 163). Bu anayasanın 12. Maddesi tüm Çin vatandaşlarının eğitim görme hakkını ve azınlıkların anadilde eğitim alma hakkını garanti altına almaktadır (Grose, 2010, s. 98). Bu anlamda Çin eğitim sisteminin benimsemiş olduğu kültürel çeşitlilik anlayışının temelleri Konfüçyanizm'in farklılıkların uyum içerisinde bir arada olması kavramına kadar geri götürülebilmektedir (Postiglione, 2014, s. 40). Bu kapsamda Çinli yöneticilerin "farklı etnisitelerin uyum içerisinde bir arada yaşaması" amacına ulaşabilmek için mevcut eğitim müfredatından bekledikleri temel işlev; tüm etnik azınlıklar tarafından ortak olarak paylaşılan ulusal aidiyet hissinin geliştirilebilmesinin sağlanmasıdır (Leibold vd., 2014, s. 1).

Çin Komünist Partisi tarafından etnik uyumun arttırılması için uygulanan eğitim politikaları 1958'e kadar Sovyet tipi eğitim modelinin özelliklerine sahipken, 1958 sonrasında Çin modelinin benimsendiği ve Çin'e özgü iki dilli eğitim politikasının uygulandığı bir yapıya dönüşmüştür (Beckett vd., 2012, s. 5). 19491958 yılları arasında benimsenmiş olan ve çok-uluslu devlet inşasını hedef alan Sovyet modeline göre Çin milletini oluşturan tüm azınlık halklar eşit statüde kabul edilmiş; tüm azınlıklara kendi dil ve alfabelerini koruyup geliştirme hakkı tanınmıştır (Zhou, 2012, s. 21). Çok-dilliliği teşvik eden Sovyet modeline göre bir ülkede çoğunluğun konuştuğu ana dil ile azınlık dilleri arasında bir merkez- çevre ilişkisi vardır (Beckett vd., 2012: 5). Buna göre kendi alfabesine sahip olan azınlık dilleri, çoğunluğu oluşturan ulusun konuştuğu anadilin uydularıdır. Bu sebeple azınlık dilleri devlet yönetimi tarafından belirli ölçülerde standardize edilerek zamanla çoğunluk ulusunun konuştuğu anadile benzer hale getirilecektir. Böylece azınlık dilleri arasındaki diyalektik farkının kapatılması ile etnik kimliklerin tek bir ulus içerisinde birleşmesi kolaylaşacaktır. Çin Halk Cumhuriyeti 1950’lerde bu modeli izlemiş ve 16 azınlık dilinin yazı sistemlerini reforme ederek standardize etmiştir (Zhou, 2012, s. 23).

Ancak 1958-1961 yılları arasında uygulanan Büyük İleri Atılım ve 1966-1976 Kültür Devrimi dönemleri Komünist parti yöneticileri tarafindan benimsenen tüm sosyal ve ekonomik politikaların olduğu gibi azınlıklara yönelik eğitim politikalarının da radikal bir şekilde dönüşmesine yol açmıştır. 1958'den itibaren Han dilinin kullanımını teşvik etmeye başlayan Komünist Parti yönetimi, Kültür Devrimi ile "tek dil konuşan tek millet" ideolojisini benimsemiştir (Zhou, 2012, s. 24). Bu kapsamda Çin Komünist Partisi yöneticileri çok-dilliliği teşvik eden Sovyet modelinin aksine “farkllıkları kapsayan tek bir millet” 中华民 族多元一体 Zhōng huá mín zú duō yuán yī tǐ görüşünü benimseyen Çin modeline geçiş yapmıştır (Zhou, 2012, s. 26). Çin modeli eğitim sisteminin en önemli k1sml, bu sistem içerisinde benimsenen anadilde eğitim politikasına ilişkin uygulamalardır. Bu kapsamda Sincan Uygur Özerk Bölgesi'nde uygulanan eğitim sistemi, 2012 yllında yayınlanan ve "Sincan Uygur Özerk Bölgesi'nde Etnik Birliğin Sağlanmasına Yönelik Eğitim Yönetmeliği” başlıklı belge ile güncel formuna ulaşmıştır (Chou, 2012, s. 4). Belge içerisinde yer alan ve eğitimin kapsamı ile yöntemini belirleyen üçüncü kısımda düzenlendiği üzere Çin’in etnik azınlıklara yönelik eğitimi aşağıdaki konuları içermektedir (Sharpe, 2012, s.19-20):

(1) Devlet, millet, din, tarih ve kültüre ilişkin Marksist kavramsal çerçeve

(2) Ulusal bilinç, sivil ve yasal farkındalık, Çin milleti bilinci

(3) Vatandaşlık, sosyalizm ve kollektivizm eğitimi

(4) Çin Komünist Partisi tarafindan benimsenen etnik teoriler, etnik ve dini politikalar ile bölgesel etnik özerkliğe ilişkin ulusal sistem

(5) Çin milletinin, Çin kültürünün ve Çin karakterli sosyalizmin tanımlanması, büyük anayurt kavramsallaştırmasının yapılması

(6) Tüm etnik grupların birliği ve ortak refahlarına ilişkin eğitim 
(7) Sincan'ın tarihine ve bölgedeki etnik kalkınmaya ilişkin eğitim

(8) Anayurdun bütünlügünün güven altına alınması, etnik ayr1lıkçıllğa, şiddet ve terörizm ile aşırı dinci eğilimlere karşı muhalefet

(9) Tüm etnik grupların gelenek ve davranışlarına sayg1 eğitimi

(10) Etnik birliğin sağlanmasına ilişkin diğer içerikler

Bu belgeye göre şekillenen eğitim sisteminde Mandarin dilinin temel eğitim dili, azınlık anadillerinin ise ikinci dil olarak kullanılması hedeflenmiștir (Cappelletti, 2015, s. 163). Mandarin dilinin temel eğitim dili olmasının yanı sıra azınlık çocuklarının ebeveynleri, müfredat içerisinde anadillerinin ne yoğunlukta verilebileceğini seçme hakkına sahiptirler. Buna göre Sincan'da üç farklı eğitim seçeneği bulunmaktadır: 民 考民 minkaomin, 民考漢 minkaohan ve 漢考漢 hankaohan. Birinci seçeneğe göre "Uygur okulları" olarak da bilinen minkaomin sistemi, azınlık anadili öğrencilere ayrı bir ders olarak verilmekte ve öğrenciler diğer dersleri Mandarin dilinde almaktadırlar (Cappelletti, 2015, s. 164). İkinci seçeneğe göre "karma okullar" olarak bilinen okullarda minkaohan sistemi, azınlık grubu öğrencileri ile Han etnisitesine sahip öğrenciler birlikte eğitim almaktadırlar. Bu okullarda okuyan azınlıklar bazı seçmeli dersleri azınlık dilinde onun haricindeki tüm dersleri Mandarin dilinde almaktadır. Üçüncü seçenek ise "Han okulları" olarak bilinen okullarda uygulanan hankaohan sistemidir. Han kökenli öğretmenlerin tüm dersleri Mandarin dilinde verdiği bu okullardaki ögrencilerin çoğunluğu Han kökenli çocuklar ve daha az sayıda fakat sayıları giderek artan şekilde azınlık çocuklardır. Sincan Eğitim Bakanlığı 2004 yılında aldığı kararla iki dilli eğitim politikasının Urumchi-Changji, Qaramay, Chöchak, Ghulja, Korla, Khotan, Turpan bölgelerini içine alan yedi bölgede kademeli geçiş yoluyla uygulamaya konulacağını ve yaygınlaştırılacağını deklare etmiştir (Schluessel, 2009, s. 394).

Sincan Uygur Özerk Bölgesi'nde ilk kez 1992'de başlatılan iki dilli eğitim politikasının temel amac1, azınlık öğrencilerinin kendi dillerini olduğu kadar Mandarin dilini de akıcı şekilde konuşmalarını sağlayarak mezuniyet sonrasında Sincan'ın içinde veya dışında istihdam edilebilmelerinin önünü açmaktır. 1999'da Sincan'da iki dilli eğitim veren 27 ortaokul ve bu okullara kayıtlı 2.629 öğrenci varken 2005 'de bu rakamlar 4,505 okul ve 145.000 'e yükselmiştir. İki dilli eğitim kapsamında Sincan'da 2000 yllında lise düzeyinde başlatılan Sincan Sınıfi 新疆班 Xīn jiāng bān uygulaması ile azınlık öğrencilerinin üniversite eğitimi alabilmesi için eğitim verilmektedir. Öğrencilerinin \%85-95’ini Uygurların oluşturduğu bu okullarda ayrıca Han, Hui, Moğol ve Kazak öğrenciler de eğitim almaktadır. 2000 yılında bu okullarda kayıtlı 1000 öğrenci varken 2011'de öğrenci sayısı 7090'a, 2012'de 8330'a yükselmiştir. 2000-2012 yılları arasında Sincan Sınıfi uygulaması kapsamında uygulamaya konan okullardan toplamda 51.000 öğrenci mezun olmuştur (Gupta, 2006, s. 316).

Çin, kabul ettiği iki dilli eğitim politikası ile özerk yönetim bölgelerinin ekonomik gelişmesinin ve ana kıta ile bütünleşmesinin sağlanacağını iddia etmektedir. Fakat devlet azınlıkların kendi anadillerinde eğitim almalarını anayasal garanti altına almış olsa da iki dilli eğitimin başlatılması bu garantileri fiili anlamda geçersiz kılmaktadır. Daha iyi eğitilmiş Han etnisiteli öğretmenler ve daha iyi kaynaklarla finanse edilen Mandarin okullarının varlığı, ilköğretimden üniversite eğitimine kadar okullar arasında bir hiyerarşi oluşmasına yol açmaktadır (Gupta, 2006, s. 307-308).

Mevcut eğitim sistemi içerisinde Mandarin dilinin hâkimiyeti, bu dilde kendini geliştirmiş öğretmenlerin Han okullarında ve Karma okullarda görevlendirilmelerine yol açmakta, bu da etnik okulların eğitim kalitesini giderek düşürmektedir (Cappelletti, 2015, s. 165). Nitekim etnik okulların eğitim kalitesine yönelik en önemli göstergelerden bir tanesi Han okullarına kayıt yaptıran azınlık öğrenci sayısının giderek yükseliyor olmasıdır. 2000 yılında Han okullarındaki azınlık öğrencilerinin sayısı 79.000 den 2005 yılında \%66’lık bir artışla 131.000'e yükselmiştir. Kaşgar Eğitim Koleji Dekanı'nın açıklamasına göre yerel Han okullarının \%70'ini Uygur çocukları oluşturmaktadır. Han okullarındaki azınlık öğrencilerin sayısındaki bu artış, iki dilli eğitimin tanımlamasının "Mandarin öğretimiyle tamamlanan yerel dilde eğitim" den "Yerel dil eğitimiyle desteklenen Mandarin dilinde eğitim”e doğru dönüştüğünü göstermektedir (Ma, 2009, s. 219). Bu kapsamda Uygur etnisitesine mensup ailelerin çocuklarının eğitiminde Han okullarını tercih etmelerinin sebeplerinden bir tanesi Mandarin dilini akıc1 şekilde konuşan çocukların iyi bir üniversitede okumalarının ve iyi bir iş bularak Çin toplumunda yüksek pozisyonlara yükselmelerinin kolay olacağına dair inançlarıdır (Cappelletti, 2015, s. 164). 


\section{Sonuç}

Çalışmada ortaya konulduğu gibi milliyetçilik modernite ile yakından ilişkilidir. Milliyetçilik modern dönemin başlarında toplum içindeki katı hiyerarşiyi yıkıp, vatandaşlık çatısı altında eşitliksizlikleri ortadan kaldırmayı amaçlamıştır. Ancak, daha sonra özellikle sivil milliyetçiliğin değil de etnik milliyetçiliğin benimsendiği ülkelerde, milliyetçilik özgürleştirici ve kapsayıcı bir güç olmaktan uzaklaşmış; dışlayıcı ve baskıcı bir güç haline gelmiştir.

Çin Halk Cumhuriyeti tarafindan Sincan Uygur Özerk Bölgesi'nde uygulanan politikalar bu durumun açık bir örneğini oluşturmaktadır. Sincan Uygur Özerk Bölgesi sahip olduğu stratejik konum ve multi-etnik yapısıyla Çinli yöneticiler için hem iç siyasal meşruiyetin hem de dış güvenliğin sağlanmasında merkezi bir öneme sahiptir. Bölgenin sahip olduğu bu stratejik önem, Sincan Uygur Özerk Bölgesi’nin siyasal ve kültürel açıdan Çin ana kıtası ile birleştirilmesini zaruri hale getirmiştir.

Çin’in bütünleştirme amaçlı izlediği politikalar çalışmada ortaya konulduğu üzere etnik milliyetçilik anlayışına uymaktadır; kapsayıcı ve özgürleştirici olmak yerine, dışlayıcı ve baskıcıdır. Modern dönem öncesinde görülen esnek ve etnisiteye göre toplumun derecelendirilmediği yapının aksine, modern dönemde Han etnisitesi merkeze konulmuş, diğer etnisiteler ise dışlanmış ve baskı altına alınmışır. Çin tarafindan Sincan Uygur Özerk Bölgesi'nde izlenen politikalar, etnik milliyetçilik kavramsallaştırmasına uygun şekilde dil, etnik köken ve kültürü temel almakta ve azınlıklar üzerinde baskı mekanizmasını etkin kılacak şekilde belirlenmektedir. Vatandaşlık temelli sivil milliyetçiliğin hâkim olduğu toplumlarda olduğundan farklı bir durum vardır. Uygurlar, ülkede bir azınlık olarak farklılıkları yüzünden ayrımcilığa maruz kalmakta; eşitsizlikle yüzleşmektedirler.

Bu kapsamda bölgede yaşayan etnik azınlı üzerinde uygulanan nüfus, eğitim ve dil politikaları sonucunda Sincan'ın etnik ve kültürel yapısı önemli ölçüde değişime uğramıştır. Han etnik kökenine sahip Çinli halkın bölgeye göçünün teşvik edilmesi ile Sincan'da Uygur ve Han nüfusu neredeyse eşit duruma getirilmiştir. Diğer yandan merkezi yönetimin uyguladığı iki dilli eğitim politikası Uygurlar başta olmak üzere tüm diğer etnik azınlıkların anadilleri yerine Mandarin dilinde eğitim almalarını zorunlu hale getirmektedir. Bu bağlamda, egemen etnik grubun dili hiyerarşinin tepesinde konumlandırılmakta, azınlık dilleri ise egemen dilin gölgesinde kalmaktadır.

1949 yılından itibaren dil, nüfus ve eğitim politikaları ile Sincan bölgesinde uygulanan fakat başarısız olan etnik-milliyetçi politikaları Çin, Mesleki Beceri Eğitim Merkezleri adını verdiği baskıcı uygulamalar ile yoğunlaştırarak devam ettirmektedir. Buna karşın Sincan'da Han Çinlileri ile azınlık gruplar arasındaki gerilimin artarak devam etmesi, Çin yönetimini bölgedeki milliyetçi politikaları üzerinde yeniden düşünmeye davet edenlerin sayısını da artırmaktadır.

21. yüzyllın ekonomik ve siyasi güç merkezi olarak ön plana çıkan, büyük güç olarak kabul edilen bir aktör olarak Çin küresel sistemde etkin olabilmek için öncelikle kendi sınırları içerisindeki barış ve refah düzenini kurma baskısı ile karşı karşıyadır. Bu aşamada Çin, etnisite temelinde yükselen bir milliyetçilik anlayışını vatandaşlı temelli kapsayıcı bir politikaya dönüştüremediği takdirde küresel bir güç olmak için gerekli iç siyasi barışa ulaşamayacaktır.

\section{Etik Beyan}

“Baskıcı ve Dışlayıc Han Milliyetçiliğinin Doğu Türkistan (Sincan Uygur Öžrke Bölgesi)'da Yansımaları” başlıklı çalışmanın yazım sürecinde bilimsel, etik ve alıntı kurallarına uyulmuş; toplanan veriler üzerinde herhangi bir tahrifat yapılmamıss ve bu çalışma herhangi başka bir akademik yayın ortamına değerlendirme için gönderilmemiştir.

\section{Kaynakça}

Adıbelli, B. (2008). Doğu Türkistan. İstanbul: IQ Yayınc1lık.

Alptekin, E. (1992). Chinese policy in Eastern Turkestan. Institute of Muslim Minority Affairs Journal, 13(1), 185-195.

Atlı, A. (2011). The role of xinjiang uyghur autonomous region in the economic security of China. $O A K A, 6(11)$, 111-133.

Başkaya, M. (2019). Arşiv belgelerine göre cumhuriyetin ilk yıllarında doğu Türkistan'ın genel durumu ve Türkiye ile kültürel münasebetler. Bilig. 89, 215-236.

Beckett G. H. ve Postiglione, G. A. (2012). China's language policy for indigenous and minority education. İçinde Gulbahar H. Beckett and Gerard A. Postiglione (Edt.), China's Assimilationist Language Policy, the Impact on Indigenous/minority literacy and social harmony. USA: Routledge-Taylor\&Francis Group.

Bendix, R. (1978). Kings or people: Power and the mandate to rule. Berkeley: University of California Press. 
Berlin, I. (1980). Vico and herder: Two studies in the history of ıdeas. London: Chatto \& Windus.

Bovingdon, G. (2004). Autonomy in Xinjiang: Han nationalist imperatives and Uyghur discontent. Policy Studies, 11, $1-64$

Caprioni, E. (2011). Daily encounters between Hans and Uyghurs in Xinjiang: Sinicization, integration or segregation? Pacific Affairs, 84(2), 267-287.

Calhoun, C. (2008). Introduction to the transaction edition. The Idea of Nationalism: A Study in Its Origins and Background, With a New Introduction by Craig Calhoun. New Brunswick and London: Transaction Publishers. IX-L.

Cappelletti, A. (2015). Developing the land and the people: Social development 1ssues in Xinjiang Uyghur autonomous region (1999-2009). East Asia, 3, 137-171.

Censer, J. R. (2001). Liberty, equality, fraternity: Exploring the French revolution. University Park, Pa.: Pennsylvania State University Press.

Chou, B. K.P. (2012). Implementation measures of China's Xinjiang policies. Chinese Law and Government, 45(4), 3-8.

Christiansen, F. ve Rai, S. (1996). Chinese politics and society-an introduction. Great Britain: T.J. Press.

Clarke, M. E. (2011). Xinjiang and China's Rise in Central Asia-A History. New York: Routledge.

Conversi, D. (2012). Modernism and nationalism. Journal of Political Ideologies, 17(1), 13-34.

Dağcı, K. ve Keskin, M. (2013). Çin'in Doğu Türkistan politikası ve azınlık hakları bağlamında hak ihlalleri. Barıs Araștırmalar ve Catısma Cö̈zümleri Dergisi, 1(2), 11-29.

Demirağ, Y. (2014). 1755-1949 y1llar1 arasında Doğu Türkistan. Uluslararası Uygur Araștrrmalarn Dergisi, 3, $229-245$.

Dillon, M. (2004). Xinjiang-China's Muslim Far Northwest, New York: Routledge Curzon Publications.

Fan, K. (2016). Representation of ethnic minorities in socialist China. Ethnic and Racial Studies, 39(12), 2091-2107.

Gellner, E. (1983). Nations and nationalism. Oxford: Blackwell.

Goldmann, K., Hannerz, U. ve Westin, C. (2016). Introduction: Nationalism and internationalism in the post-cold war era. İçinde Kjell Goldmann, Ulf Hannerz and Charles Westin (Edt.), Nationalism and Internationalism in the Post-Cold War Era (pp. 1-22). London: Routledge.

Gökalp, E. (2007). Milliyetçilik: Kuramsal bir değerlendirme. Anadolu Üniversitesi Sosyal Bilimler Dergisi, 7(1), 279-298.

Greenfeld, L. (1996). Nationalism and modernity. Social Research, 63(1), 3-40.

Greenfeld, L. (2006). Modernity and nationalism. İçinde Gerard Delanty and Krishan Kumar (Edt.), Handbook of Nations and Nationalism (pp. 157-168). Thousand Oaks, CA: SAGE Publications.

Grose, T. A. (2010). The Xinjiang class: Education, integration and the uyghurs. Journal of Muslim Minority Affairs, 30(1), 97-109.

Harris, E. (2009). Nationalism: Theories and cases. Edinburg: Edinburg University Press.

Howell, A. ve Fan, C. C. (2011). Migration and 1nequality in Xinjiang: A survey of Han and Uyghur migrants in urumqi. Eurasian Geography and Economics, 52(1), 119-139.

Joniak-Lüthi, A. (2016). Blurring boundaries and negotiating subjectivities - the Uyghurized Han of southern Xinjiang, China. Ethnic and Racial Studies, 39(12), 2187-2204.

Karaca, R. K. (2007). Türkiye-Çin Halk Cumhuriyeti ilişkilerinde Doğu Türkistan sorunu. Gað̧i Akademik Bakış, 1(1), 219-245.

Karluk, A. C. (2017). Uygur Türk toplumunda değişmenin sonucu olarak aydınlarda bölünmüşlük ve kültürel kopukluk. Türklük Bilimi Arastırmalar, 22(42), 171-204.

Kaufmann, E. ve Oded, H. (2008). Dominant ethnicity: From minority to majority. Nations and Nationalism, 14(4), 743-767.

Kedourie, E. (1993). Nationalism. New York: Wiley Publishers.

Keitner, C. I. (2007). The paradoxes of nationalism: The French revolution and its meaning for contemporary nation building. New York: State University of New York Press.

Kohn, H. (1994). Western and eastern nationalism. İçinde John Hutchinson and Anthony D. Smith (Edt.), Nationalism (pp. 162-165). Oxford: Oxford University Press.

Körpe, Ö. (2013). Doğu Türkistan'da yeni nesil çatışmanın iki boyutu: Şiddet dışı ve silahlı mücadelelere ilişkin bir stratejik analiz. İçinde R. Kutay Karaca (Edt.). Asya'da güvenlik sorunlar ve yansımalar (ss. 15-56). İstanbul: Bilgesam Yayınları.

Kymlicka, W. (1995). Multicultural citizenship. Oxford: Clanderon Press.

Laifong, L. (2005). Xiafang - xiaxiang. İçinde Edward L. Davis (Edt.), Encyclopedia of contemporary Chinese culture. Routledge: USA.

Leibold, J. ve Chen, Y. (2014). Minority education in China-Balancing unity and diversity in an era of critical pluralism. Hong Kong University Press: Hong Kong.

Li, S. (2013). Sinciang Uygur Taribi. İstanbul: Kaynak Yayınlar1.

Ma, R. (2009). The development of minority education and the practice of bilingual education in Xinjiang Uyghur autonomous region. Front. Educ China, 4(2), 188-251.

Ma, R. (2014). Reflections on the debate on China's ethnic policy: my reform proposals and their critics. Asian Ethnicity, 15(2), 237-246.

Ma, R. (2017). Reconstructing "nation” (minzu) discourses in China. International Journal of Anthropology and Ethnology, $1(8), 1-15$.

Marx, A. W. (2003). Faith in nation: Exclusionary origins of nationalism. Oxford University Press: Oxford 
Maurer-Fazio M. ve Hasmath, R. (2015). The contemporary ethnic minority in China: an introduction. Eurasian Geography and Economics, 56(1), 1-7.

Millward, J. A. ve Perdue, P. C. (2004). Political and cultural history of the Xinjiang Region through the late nineteenth century. İçinde S. Frederick Starr, (Edt.), Xinjiang, China's Muslim Broaderland (pp. 27- 62). New York: M. E. Sharpe.

Millward, J. A. (2007). Eurasian crossroads, A history of ximjiang. New York: Columbia University Press.

Nairn, T. (1975). The modern janus. New Left Review, 94, 3-30.

Norbu, D. (1988). Chinese communist views on national self-determination, 1922-1956: Origins of China's national minorities policy. International Studies, 25(4), 317-342.

Odgaard, L. ve Nielsen, T. G. (2014). China's counterinsurgency strategy in Tibet and Xinjiang. Journal of Contemporary China, 23(87), 535-555.

O'Mahony, P. ve Gerard D. (2002). Nationalism and social theory. Londra: SAGE Publications.

Pekcan, C. (2017). Konfüçyüs felsefesinin dış politikaya etkisi bağlamında 2003-2013 Yılları Arası Çin-ABD İlişkileri. Ankara Üniversitesi SBF Dergisi, 72(4), 1127-1155.

Plamenatz, J. (1973). Two types of nationalism. Nationalism: The nature and the evolution of the idea (pp. 22-38). (Der: E. Kamenka). Canberra: Australian National University Press.

Postiglione, G. (2014). Education and cultural diversity in multiethnic China. In J. Leibold ve C. Yangbin (Eds.), Minority education in china-calancing unity and diversity in an era of critical pluralism (pp. 27-43). Hong Kong: Hong Kong University Press.

Roshwald, A. (2001). Ethnic nationalism and the fall of empires. Londra ve New York: Routledge.

Sayın Y. ve Koçak, G. (2017). Müslüman dünyanın bir sorun alanı olarak Doğu Türkistan meselesi ve Çin Halk Cumhuriyeti’nin izlediği politikalar. Journal of Ottoman Civilization Studies, 3(4), 10-24.

Schluessel, E. T. (2009). History, identity and mother tongue education in Xinjiang. Central Asian Survey, 28(4), 383402.

Schmidt, V. H. (2010). Modernity and diversity: Reflections on the controversy between modernization theory and multiple modernists. Social Science Information, 49(4), 511-538.

Sharpe, M .E. (2012). Xinjiang Uighur autonomous region ordinance on education for ethnic unity. Chinese Law \& Government, 45(4), 15-22.

Shih, C. (2002). Ethnic economy of citizenship in China: Four approches to identity formation. İçinde Merle Goldman and Elizabeth J. Perry (Edt.), Changing Meanings of Citizenship in Modern China, Harvard University Press: Cambridge.

Smith, A. D. (1998). Nationalism and modernism: A critical survey of recent theories of nations and nationalism. London and New York: Routledge

Starr, S. F. (2004). Xinjiang, China's Muslim Broaderland, M. E. Sharpe, New York: Routledge.

Tilly, C. (1975). "Reflections on the History of European State-Making". İçinde Charles Tilly (Edt.), The Formation of National States in Western Europe. Princeton: Princeton University Press. 3-83.

Toops, S. (2004). "Demographics and Development in Xinjiang after 1949", East-West Center, Working Paper No.1, May 2004, Washington. https://pdfs.semanticscholar.org/ 431a/96153009b330bfea29a2fadd980750a6edf9.pdf (e.t. 16.07.2019).

Toops, S. (2016). "Spatial Results of the 2010 Census in Xinjiang", March 7, 2016, https:/ theasiadialogue.com/2016/03/07/spatial-results-of-the-2010-census-in-xinjiang/ (e.t. 16.07.2019).

Waley-Cohen, J. (2004). The New Qing History. Radical History Review, 88, 193-206.

Walzer, M. (1999). “The New Tribalism: Notes on a Difficult Problem”. İçinde Ronald Beiner (Edt.), Theoriz̨ing Nationalism. New York: State University of New York Press. 205-217.

Wimmer, A. (2002). Nationalist Exclusion and Ethnic Conflict: Shadows of Modernity. Cambridge: Cambridge University Press.

Wu, X. ve Xi, S. (2013). Ethnicity, Migration and Social Stratification in China: Evidence from Xinjiang Uyghur Autonomous Region Population Studies Center Research Report 13-810, November 2013.

Wu, X. ve He, G. (2018). Ethnic Autonomy and Ethnic Inequality: An Empirical Assessment of Ethnic Policy in Urban China. China Review, 18 (2), 185-216.

Xinjiang Uyghur Autonomous Region, China- A Cultural and Historical Dictionary (Ed.) Michael Dillon, 1998, Great Britain: Curzon Press.

XPCC- int: Establishment, "Development and Role of the Xinjiang Production and Construction Corps", http://www.china.org.cn/e-white/20030526/9.htm (e.t.06.11.2015).

Zhou, M. (2012). Historical review of the PRC's minority/indigenous language policy and practice-Nation-state building and identity construction. İçinde Gulbahar H. Beckett and Gerard A. Postiglione (Edt.), China's Assimilationist Language Policy, the Impact on Indigenous/minority Literacy and Social Harmony, , USA: RoutledgeTaylor\&Francis Group.

\section{EXTENDED ABSTRACT}

Among the 56 ethnic groups recognized by the Chinese Constitution, Uighur Turks are one of the biggest, and the Xinjiang Uighur Autonomous Region is the largest of five autonomous regions of the 
People's Republic of China. As it possesses rich natural resources and borders eight states, Xinjiang is strategically significant for Beijing. Therefore, Xinjiang looms large in the national integration policy of China. For Beijing, establishing political control over Xinjiang is not only crucial for security reasons, but it also can provide the Communist Party with an instrument to consolidate its economic and political legitimacy. This study explores the population, education, and language policies pursued by Beijing in the Xinjiang Uyghur Autonomous Region from the perspective of modernity and nationalism. As a conclusion, the study argues that rather than opting for emancipatory and inclusionary policies, in Xinjiang, China pursues ethnic nationalist policies that are repressive and exclusionary.

In East Turkistan or officially named Xinjiang Uighur Autonomous Region, the oppressive nationalist policies of the People's Republic of China and the increasing reactions against these policies have prepared a ground to resume discussions about nationalism theories and the changing reflections of nationalism in Eastern and Western societies. As a matter of fact, although the 19th century is an absolute backward period for China, it was the 19th century when nationalism first appeared in China, as in Europe. In addition, while nationalism in Continental Europe gained a rising civil and inclusive character on the basis of citizenship, nationalism in China has become exclusivist by shaping on belonging to a certain ethnic group and culture.

Nationalism aimed at destroying the rigid hierarchy in the society at the beginning of the modern period and eliminating inequalities under the roof of citizenship. However, later on, in countries where ethnic nationalism was adopted, rather than civilian nationalism, nationalism was no longer a liberating and inclusive force; it has become an exclusive and oppressive force.

The policies implemented by the People's Republic of China in the Xinjiang Uighur Autonomous Region are a clear example of this situation. With its strategic location and multi-ethnic structure, Xinjiang Uighur Autonomous Region has a central importance in ensuring both domestic political legitimacy and external security for Chinese executives. This strategic importance of the region has made it necessary?????? to unite the Xinjiang Uighur Autonomous Region politically and culturally with the mainland of China.

The policies pursued by China for integration fit the understanding of ethnic nationalism as outlined in the study; Instead of being inclusive and liberating, it is exclusive and oppressive. Contrary to the flexible and ethnic structure seen before the modern period, Han ethnicity was put in the centre in the modern period, other ethnicities were excluded and oppressed. The policies pursued by China in the Xinjiang Uighur Autonomous Region are based on language, ethnicity and culture in accordance with the concept of ethnic nationalism, and are determined in a way to make the pressure mechanism on minorities effective.

Uighurs are discriminated against because of their differences as a minority in the country; they face inequality. In this context, as a result of the population, education and language policies implemented on the ethnic minority living in the region, the ethnic and cultural structure of Xinjiang has changed significantly. By encouraging the Chinese people of Han ethnic origin to migrate to the region, the population of Uyghur and Han was almost equal in Xinjiang. On the other hand, the bilingual education policy implemented by the central government makes it mandatory for all other ethnic minorities, particularly Uyghurs, to receive education in Mandarin instead of their mother tongue. In this context, the language of the dominant ethnic group is positioned at the top of the hierarchy, while minority languages are overshadowed by the dominant language.

Since 1949, China has continued its language, population and education policies, and the ethnicnationalist policies implemented in the Xinjiang region, but have failed by intensifying the repressive practices they call Vocational Skill Training Centres. On the other hand, the increasing tension between Han Chinese and minority groups in Xinjiang increases the number of people who invite the Chinese administration to rethink their nationalist policies in the region.

As a result of the study, it was revealed that China implemented policies based on the understanding of ethnic nationalism in accordance with the classification made by Kohn in the Xinjiang Uyghur Autonomous Region, and in this context, population, education and language policies were used as an oppressive and exclusive power, not liberating and inclusive. As an actor that stands out as the centre of economic and political power of the 21 st century and is accepted as a great power, China is faced with the pressure to establish peace and prosperity within its borders in order to be effective in the global system. 
At this stage, if China cannot transform an understanding of nationalism rising on the basis of ethnicity into an inclusive policy based on citizenship, it will not be able to achieve the necessary domestic political peace to become a global power. 